\title{
Director Notes \\ Evaluating boards: A policy agenda in need of perspective
}

\author{
By Donald Nordberg and Rebecca Booth ${ }^{1}$
}

This analysis was published in July 2019 by The Conference Board Inc. It forms a part of its "Director Notes" series for member organizations

(https://www.conference-board.org/publications/publicationdetail.cfm?publicationid=8637).

For at least 30 years, and with growing intensity through recurring corporate governance crises, public policy in many countries has been striving to encourage boards of directors to undertake regular evaluations. The policy push has stimulated much practical advice, many tools for evaluation, strong encouragement from professional bodies, and considerable skepticism from those being evaluated. While some scholars have sought to conceptualize the practice, we lack a fuller understanding that can help us see how the promised benefits and feared drawbacks arise. This Director Notes report reviews the policy context and practitioner accounts and builds frameworks for practice and policy analysis. The authors find that board evaluation is a multidimensional concept in which the interactions across the dimensions open paths to improvement of boards processes while also to unintended consequences. The authors then suggest avenues for future research and a shift in policy and practice toward greater experimentation.

\section{Introduction}

Following corporate failures around the world in the first years of the 2000s, and with growing urgency after the global financial crisis of 2007-09, the search for better corporate governance has looked inside the boardroom, emphasizing director independence, behavioral change, and a focus on relationships between directors. With that came a new and seemingly undramatic policy direction: to understand the impact of these changes, boards should regularly, and conscientiously, evaluate their performance. ${ }^{1}$

The policy direction has become institutionalized, focusing attention of boards, investors, consultants and others on the practice, leading to widespread changes in behavior in corporations around the world. And while the policy demand for board evaluation started with listed companies, the practice has spread far beyond them, into public bodies, private firms, the charitable sector, and clubs and associations. This direction has begun to attract scholarly attention, but the limited range of work to-date suggests the need for fuller conceptual understanding and different approaches to research, which this paper starts to address.

\footnotetext{
${ }^{1}$ Donald Nordberg is Associate Professor of Corporate Governance at Bournemouth University in the UK and a former senior adviser to The Conference Board Europe. He is also chairman of a large charity in Britain and has served on other company and charity boards.

Rebecca Booth is a financial services specialist in Guernsey who has had direct professional engagements in board evaluations for several UK listed companies.
} 
The first wave of theorizing of corporate governance led to policy and practice changes largely without consideration of boards, focusing instead on the agency problem, which arises from the separation of corporate ownership and control. ${ }^{2}$ Agency theory suggests that information asymmetries between shareholders, the "principals" in a business, and the managers who run them as "agents" of the owners can lead self-interested managers to expropriate corporate resources for their own purposes, or to shirking of their responsibilities. The remedies the theory proposes - increased disclosure and shareholder rights, coupled with managerial incentives linked to shareholder value - changed the informal rules governing top management teams and their relations with investors. But they left the board itself largely unexamined.

A shift toward greater control and interest in the mechanics of boards followed, which prompted the UK to adopt a code of corporate governance, which inspired other countries to take similar actions. ${ }^{3}$ Such codes dealt mainly with structure, while remaining silent on the inner workings of boards. That changed following the wave of corporate failures, in many countries and especially the US, in 2000-03, which opened the door for policy to move into the boardroom, specifically by asking boards to undertake regular assessments of their own performance.

The impetus for board evaluation has generated much advice from professional bodies, consultancies, and well-intentioned directors and other practitioners, practitioner articles in academic journals, and practice-oriented writing by academics. ${ }^{4}$ These writings generated frameworks and checklists for practice, some combining ideas from employee performance appraisals with insights about the peculiarities of boards. ${ }^{5}$ Theoretical and empirical understanding of board evaluation is, however, comparatively underdeveloped. This report reviews the nascent but growing literature on board evaluation. Its contributions lie, first, in integrating ideas from existing conceptual studies; second, and drawing on institutional theory and attention, in taking steps towards articulating reasons for resistance to the practice; and third, in suggesting research that can contribute to a stronger evidence-base for policy.

To achieve that, the authors review the first policy context, then advice from professional bodies, organizations, and individuals engaged in evaluation. Next, the authors summarize the academic work, reviewing conceptual papers, ones concerned with content and process elements, and tools for evaluation exercises, and then the handful of empirical studies to-date. The authors summarize these ideas in a model of themes to be considered in board evaluation, highlighting those best undertaken with the help of external evaluators.

\section{Board evaluation in policy, practice, and concept}

Concern for board evaluation has a long history, in theory if not in practice. The earliest mention of board evaluation in our search came from a practice-focused article in Harvard Business Review in 1950, in which Wilbur Blair discussed how difficult it is to appraise the quality of a board, but urged action by boards nonetheless. ${ }^{6}$ There is little evidence that much came from it. 
A similarly skeptical account came in 1991 on the potential of self-assessment by boards, in his case those of non-profit organizations, which cast doubt on the "sage advice" of popular books opining "ideal principles of action" of boards. ${ }^{7}$

As practice and policy preceded conceptual work and evidence, this report starts with a brief overview of the burgeoning if largely untheorized policy, professional, and practitioner recommendations. And assessment of academic literature follows with papers concerned with process and content questions, and normative analyses and tools, and conceptual thinking on evaluation. Then it examines the nascent empirical literature to summarize the evidence that can begin to inform theory.

\section{Policy directions}

Corporate failures in the early 1990s in the UK shone a spotlight on boards, setting a policy direction widely copied around the world. The Cadbury Code urged new board structures, including the separation of the role of chair and CEO, to overcome the agency problem arising from the separation of ownership and control. The Cadbury Committee deliberated over recommending board evaluations only to back away. A first move toward institutionalization came from the Toronto Stock Exchange, which in 1994 sought self-assessments by listed company boards and disclosures about this and 13 other guidelines. The first French corporate governance code also recommended regular board evaluation, with disclosure. In the early years, acceptance was somewhat slow. ${ }^{8}$

The collapse in the early 2000s of Enron, WorldCom, and many others in the US, and in other countries (e.g. Parmalat/Italy, HIH/Australia, Ahold/Netherlands), brought new concern about boardroom behavior and the relationships between directors, which led to attention to evaluation. The policy spread informally, from recommendations by director associations and stock exchanges into codes of best practice: boards should systematically appraise their own performance. In the US, the National Association of Corporate Directors (NACD) issued a "Blue Ribbon Commission" report urging adoption of regular self-assessment. The New York Stock Exchange recommended annual board self-evaluations in its listing rules, while a new UK code recommended the practice for larger companies. That code's spirit then informed codes in other countries and multilateral guidance. These recommendations met with broad, if somewhat reluctant, compliance.

The 2007-09 global financial crisis brought renewed policy initiatives. The King corporate governance code in South Africa in 2009 recommended board evaluations, giving boards discretion over whether to conduct them internally or to use an external adviser. A renamed UK Corporate Governance Code retained much of the language on board evaluation from 2003 while adding a further recommendation: board evaluations at the 350 largest listed companies "should be externally facilitated at least every three years"; boards should also state whether the external facilitator had "any other connection" with the company. Through subsequent revisions this recommendation remained. This time the idea gained increasing acceptance and in policy beyond the UK. ${ }^{9}$ Such a generic specification leaves much discretion 
with boards and their chairs; moreover, the recommendation falls under the general complyor-explain provision of the code, making its application voluntary.

The new policy direction was copied in other jurisdictions in the next few years, and advocated by professional bodies and other authorities. As codes of corporate governance increasingly advocated the practice, professional bodies and consultants beat a drum to energize compliance.

\section{Practitioner experiences}

Through the 1990s, a board consultant who had worked with Cadbury and on development of other national codes, identified growing shareholder pressure for board "performance and conformance." Writing in an academic journal, Bob Garratt urged both director development and assessment of boards as ways to professionalize their work without providing specific recommendations about how to conduct evaluations. ${ }^{10}$

As the practice began to develop, various writers made pleas for action in the pages of Harvard Business Review. ${ }^{11}$ As it proliferated, so did recommendations of professional bodies, think tanks, and consultants. Building upon her doctoral study of non-executive directors and her work as a professional board evaluator, Tracy Long declared director evaluation 'this year's model." The phrase seemed to capture a dilemma in emerging practice: Descriptively, she identified that evaluation had become fashionable, with growing numbers of checklists, questionnaires, and toolkits. Normatively, she argued that evaluation processes should reexamine each year's contingencies in the business environment, rather than following a strict template. ${ }^{12}$

Despite all this backing, the practice has met resistance. A global survey by McKinsey, which included improving board performance as one of its investigations, found only 20 percent of directors thought individual evaluations of directors were excellent or very good, while 42 percent thought the process needed improvement or needed significant improvement. ${ }^{13}$ Directors report difficulties with achieving candor, raising concern that evaluation will lack rigor owing to director non-engagement with the process. ${ }^{14}$ Reviewing 16 countries, the recruitment firm Spencer Stuart found that 43 percent of UK firms used external facilitators, but only 12 percent of companies in Norway, Sweden, and Finland did, and no Polish company reported the practice. ${ }^{15}$

Many of these discussions adopt a common-sense approach, often focusing on the content of the evaluation, rather than the process, and largely unsupported by theory. Some invoke analogies to the value of employee performance appraisal as justification, while others just assume the effort brings value. What they often lack is both conceptualization of board evaluation and empirical evidence from practice. 


\section{Conceptualizing board evaluation}

Most attempts to build a more conceptual view of board evaluation consider content and process questions together or identify tools for use in the process. Our reading of the literature also finds a small number go further, seeking to build frameworks for research or practice.

Content and process. What should boards evaluate, and how should they do it? Drawing on their experiences with several large US firms, Conger et al. identify two types of subjects for evaluation: board activities (strategy development, implementation monitoring, etc.) and resources available to the board (e.g. knowledge, skills, information, the board's authority, director motivation, time). ${ }^{16}$

On process, Kiel, Nicholson, and Barclay describe seven steps, identifying: the objectives, who will be evaluated, what subject the process will cover, who will be asked, what techniques will be used, who will conduct the evaluation, and what will happen with the results. ${ }^{17}$ Minichilli et al. condense these into four: the agent who evaluates, the content to be evaluated, the addressee or audience of the evaluation, and the method of evaluation. ${ }^{18}$ Both these approaches have been widely cited and seem to inform practice-based accounts.

In a short paper aimed mainly at practitioners, Daily and Dalton urge formalized processes including measurable variables and well-developed instruments for three levels of data collection (board, committees, and directors). They highlight the "who evaluates" question, asking boards to consider whether the process should be led by the board as a whole, the chair, an external facilitator, or a governance committee monitoring board performance. They also advise that evaluations should be backed by a data retention policy, because, under US law, such documents might be discoverable in lawsuits. ${ }^{19}$ They thus imply an outside audience.

Epstein and Roy urge a catalogue of issues for evaluation: board structures, director knowledge and skills, information systems and codes of ethics, and for the CEO a 360-degree appraisal modelled on the popular human resources practice for employees, and seeking views from a variety of outside stakeholders. Schmidt and Brauer fear evaluation processes might leave out board contributions to strategy by focusing on issues highlighted in governance metrics. They propose a process that includes formal strategy consistency analysis. ${ }^{20}$

Tools for evaluation. The content and process literature and practitioner accounts of evaluation diverge about the tools needed to assess boards. Should they use metrics to create rigor, or observation to seek out nuances in behavior and dynamics? Should they be standardized for comparability, or individualized to the contingencies of the firm, industry, and contemporary concerns? Proliferation of practice has led to tools for board evaluation. Some work from roots in the content and process discussion, incorporating board-specific issues; others are oriented in employee-oriented performance appraisal. They are often based on practical experience, some with anchors in theories of board effectiveness. 
Heracleous and Lan offer a 20-question tool to evaluate directors, focusing on their knowledge and skills, that is, inputs to board work, but not their behavior or performance. Aly and Mansour reconstruct the balanced scorecard to take into account customer-oriented metrics to the work of boards. ${ }^{21}$

Some of the instruments focus on board improvement. For example, Van den Berghe and Levrau offer a framework seeking the right fit of directors to the circumstances of the firm, while shying away from measurement. ${ }^{22}$ Likierman presents a 10 -question guide to encourage conversation, and then urges face-to-face discussion to iron out issues between directors. ${ }^{23}$ Other instruments point firmly at external consumption. In the UK, the Institute of Directors suggests using a "good governance index," seeking to make assessment verifiable to external stakeholders. $^{24}$

Conceptual studies. In one of a series of early studies concerning board practice and evaluation, Ingley and Van der Walt consider the knowledge and skills directors need for their work on strategy, with implications for director selection and board evaluation. ${ }^{25}$ They draw attention to the business context, economics and industry dynamics, the impact of legislation and regulation, and ownership issues. They then focus on board composition, director characteristics and interpersonal relations as contributors to board effectiveness. Their model becomes, in effect, a framework for board evaluation focused on improving board effectiveness.

Developing a theme from their work on board effectiveness, the practitioner-academics Kiel and Nicholson discuss three of the seven steps in their process as categories:

- First, objectives may be for 1) "corporate leadership", such as demonstrating commitment to performance or to director developments; or 2) resolving problems. [In a later paper, list five reasons for conducting evaluations: identifying areas for improvement, presenting a model of good performance to the executives and managers, signaling to stakeholders, complying with regulation, and protecting directors, each of which can be seen as components of the original two.]

- Second, audiences may be internal to the board, or external, including employees as well as outside parties.

- Third, who evaluates may involve board-internal evaluations or ones led by external facilitators. ${ }^{26}$

Minichilli et al. discuss the final two of these dimensions as continua, rather than dichotomies. Audiences for the results range from directors as individuals, to committees, academics or other researchers, external committees, investors, or regulators, increasingly distant from the board. Evaluators may be directors themselves, a board committee, consultants, researchers, or independent external agents. They discuss objectives in terms of the purpose of the evaluation, and their analysis of purpose points toward external considerations of accountability and reputation, and internal ones of board culture and knowledge resources. ${ }^{27}$ 
Taking a direction focused on data, Stybel and Peabody identify four categories of board evaluations:

1) the informal, where confidentiality is less important and collection is less structured,

2) the legalistic, with a low structure of collection of information where confidentiality is important;

3) the trusting, in which less sensitive data are gathered in a structured way; and

4) the systematic, with structured collection of the confidential data as well. They see boards evolving from the informal toward the systematic as they gain familiarity with and shed anxiety about the process. ${ }^{28}$

Other studies, however, cast a critical eye on how board evaluations will be seen and used. Jauncey and Moseley-Greatwich worry that evaluation processes may lead to categorization of directors in ways that will inhibit their participation, arguing for evaluations of individuals' behavior to be assessed by keeping definitions fluid. Long notes that even though evaluations may start as self-improvement exercises, shareholders may expect more drastic action. She argues that associated with template-driven approaches, board evaluations can become blunt instruments, lacking in sensitivity to context. ${ }^{29}$

Board evaluation processes may also lose the confidence of the directors themselves if, like employee appraisals, they come to be seen as instruments of discipline by external audiences, as well as their board colleagues. In a study for the Dutch Central Bank in its supervisory role over financial services companies, Groothuis notes that directors are often wary that external facilitators may not understand the complexities of the issues boards face. ${ }^{30}$ Griffin et al. think evaluation exercises will falter if directors become disengaged from the process. ${ }^{31}$

Why would they? Because Nicholson et al., among others, see a split in the internal uses: evaluations may lead to director development, or to changing the mix of knowledge and skills on the board. ${ }^{32}$ The latter may involve changing selection criteria for new directors, but another use may be to orchestrate the departure of directors the evaluators deem to be underperforming.

\section{Empirical evidence}

These conceptual analyses raise issues that can only be decided empirically, work that is still in its infancy. It is clustered around work by a handful of pioneering teams of scholarpractitioners. Others are small-scale qualitative studies, on specialized sectors, specialized problems, descriptive surveys, or based only on public disclosures. ${ }^{33}$

An early empirical study of board evaluation by Ingley and Van der Walt views board evaluation as an inherently political process. In this qualitative account of New Zealand boards, directors warn of "mindless checklists" and "over-engineering." ${ }^{34}$ An undercurrent in their comments, however, is that horizontal evaluation - by peers - involves different 
political/power constellation than vertical appraisals in employment relations. Some saw evaluation by and of peers as a threat to board cohesion. Such political issues were among the reasons boards decided not to undergo evaluation. In a survey of UK company secretaries, Dulewicz and Herbert find evidence that board evaluations is instrumental in boardroom change, influencing director selection and also leading to decisions by directors to resign. ${ }^{35}$

More recent studies, conducted as the practice began to be more prevalent, show board-internal benefits arising from evaluation. In a report for an association of pension investors in Australia, the academic researchers Clarke and Klettner see board evaluations leading to outcomes including changes to process, to committee structures, and even to board composition to address dysfunction. ${ }^{36}$

Looking at boards of small Norwegian firms, Nordqvist and Minichilli find strong support among directors surveyed for the of use of "board maintenance" tools, such as regular board evaluations. Regular evaluation was associated with stronger director involvement in strategy issues, resource provision, and monitoring. ${ }^{37}$ Machold et al., who also studied small Norwegian firms, use board evaluations as a component of an independent variable termed "board development", which then contribute significantly to team production of strategy. ${ }^{38}$ Their method was not able to isolate the impact of evaluations themselves, however. In a conference paper reporting on a survey of chairs of 89 Canadian listed companies, Roy finds that firms with highly articulated board performance evaluation systems were associated with higher quality director feedback, improvement in board effectiveness, engagement with strategy and monitoring, and return of assets. ${ }^{39}$

Similarly, Del Brio et al., in a study of 160 directors of companies in Canada, Spain, and Singapore, find evidence that conducting regular board evaluations is associated with the directors' effort in resource provision and with directors' perception of the CEOs trustworthiness, measured by CEOs' ability, benevolence, and integrity. But in their study, evaluation is not clearly linked to directors' monitoring role. ${ }^{40}$

Other empirical studies offer suggestions of topics only partially captured in conceptual work. The lack of detail in public disclosure raises questions about the degree to which board evaluation can attempt simultaneously to satisfy internal purpose of board development and accountability to external parties. Current policy initiatives seek only limited disclosure, but the literature the authors reviewed includes normative calls for much more complete public discussion.

A recent interview-based study identifies the mixed views of the directors toward the benefit of the use of external facilitators, although the results would be taken more seriously there was concern regarding the ability of the evaluator. As the practice expands to an increasing range of organization types, it suggests a need to consider ways of professionalizing the process. ${ }^{41}$ That echoes normative views in which evaluation leads to professionalization of directors themselves and a practitioner-led attempts to codify evaluation processes and certify evaluators. A thematic summary of the literature appears in

Table 1 (see below). 


\section{Toward a theory of board evaluation}

Conceptual work and the nascent empirical literature point toward a need to integrate themes into a more comprehensive understanding if we are to be able to develop a theoretical view of board evaluation. This section draws together these ideas and incorporate anxieties about the process, potential downsides, and the risks of manipulation of its intent to synthesize our knowledge of evaluation and develop an agenda for further research.

\section{An integrative view}

In integrating these conceptualizations, it is helpful to note that three of the seven steps advanced by Kiel and Nicholson involve dichotomies: the types objectives served by board evaluation, the audiences served, and who evaluates, each with internal and external dimensions. ${ }^{42}$ The four-step process in Minichilli et al. yields an analytic framework focused on audiences and evaluators, with the third (objectives) reflected in the purpose of evaluation. ${ }^{43}$ These dimensions focus attention on certain parts of rules of the game, embedding those while also limiting the ability of actors to pay heed to others. This approach helps us to present observations based on empirical and normative studies to build a more nuanced understanding of board evaluation.

Objectives. In the various works of Kiel and Nicholson, the diverse possible objectives fall into two categories: 1) demonstrating commitment to performance and good governance, and 2) problem resolution. The former suggests a symbolic function associated with accountability; the latter is operational, concerned with effectiveness. Their discussion of the implications and those of normative writings of other scholars and practitioners suggest that both types of objectives are important and warrant the attention of boards.

However, regulations and codes of best practice increasingly urge disclosure of the information about the evaluation process, with the danger the practice will value form over substance. If boards come to view evaluations principally as symbolic, there is a danger the process can be used in a manipulative way. Such an issue is already well documented in the corporate governance literature, in the ways that boards engage in symbolic management to manipulate how financial markets evaluate firm performance, particularly on non-financial matters. ${ }^{44}$ This concern lies beneath the recommendations in McIntyre and Murphy of the possibility of "board agency" and their call for even greater disclosure about evaluation work. ${ }^{45}$

Audiences. Similarly, the uses and therefore users of evaluations involve two types of audience: the board itself and external parties. Among the former, Kiel and Nicholson cite benefits for the organization, the board, and directors arising from leadership, role clarity, decision-making, communication, operations, and teamwork. Among the latter, they mention accountability to employees, customers, suppliers, and other stakeholders. In the current policy-led environment, regulators and stock exchanges may be added. Minichilli et al. urge us to consider audiences as a continuum between the narrowest (an individual director) and 
the most distant (regulators). Stybel and Peabody, rather provocatively, add potential bidders looking to take over the company, as well as providers of directors and officers (D\&O) insurance. ${ }^{46}$

External and internal audiences both benefit from the increased accountability of the board, but it may be useful to recall that the type of accountability may differ. The external audience, and in particular shareholders of listed firms, represent a hierarchical or vertical accountability, which Roberts calls "individualizing" in that it holds individuals to account. ${ }^{47}$ The internal audience, however, made up of fellow directors, represents a horizontal accountability, echoed in directors' concerns over the potential for a loss of cohesiveness and wariness about using instruments of appraisal of subordinates' performance in the evaluation of peers. This type of accountability is what Roberts calls "socializing", in which face-to-face encounters over extended periods of time may overcome the agency problem through generation of collective will. Here, again, attention to the outward-facing, hierarchical accountability may lead to boards becoming less attentive to the interpersonal accountability and thus overlook that side of board evaluation.

Who evaluates. Kiel and Nicholson pose a dichotomy between evaluations conducted internally (led by the chair, an independent director, or a committee) and those conducted with external assistance (through general advisers or specialist consultants). Again, Minichilli et al. bring a nuance to their framework by suggesting a continuum between internally conducted self-assessments, to assigning the role to a board committee, using consulting firms that know the company, employing researchers even less connected to the firm, or an external specialist. This range of actors suggests a growing degree of independence of the evaluator from the evaluated.

The literature shows skepticism about the effectiveness of self-assessment. The executive search firm Spencer Stuart advises that self-evaluation is insufficient as a route to board improvement, while Long advocates external evaluation for its greater objectivity. ${ }^{48}$ These are interested parties, to be sure, both interested in promoting external facilitation. But while parts of the literature show skepticism about external facilitation, the recent policy push seems to have created greater familiarity with the process, less concerns about potential downsides, and growing understanding of the benefits.

The difficulty here is understanding what external facilitation entails. For example, a practitioner-focused magazine article describes a self-assessment exercise that uses an outside party to gather and analyze data. ${ }^{49}$ Some self-assessments use templates devised by external parties for their presumed expert construction and their ease of application. This may help a board that lacks expertise in evaluation. But it also focuses attention on form over substance, which then institutionalizes into a shallow process or even a merely symbolic one.

Integrating the dimensions. The frameworks of Kiel and Nicholson and Minchilli et al. are often cited in the developing academic literature and echoed in practitioner-focused 
accounts, which attests to their usefulness. The discussion above suggests, however, a need for greater attention to the potential downsides of board evaluation. For example, on the "board improvement" aspect of the "objectives" dimension, and for internal audiences and pertaining to self-evaluation, empirical accounts suggest concerns about political undercurrents associated with director removal. To what extent these lead to consolidation of boardroom power and the stifling of debate? Using external facilitators is meant to increase objectivity and remedy the political element, but their engagement could be symbolic as much as substantive, owing to information asymmetries subject to capture under the direction of, say, a manipulative chair. Such concerns seem to underpin the calls for professionalization from practitioners, and as reported by scholars. ${ }^{50}$

\section{Things to consider}

The practice and normative academic literatures and policy directives often describe these dichotomies as "both-and" choices, rather than "either-or". The empirical literature is insufficient to guide practice in favor of one direction rather than the other. For example, findings on how evaluations affect directors' contributions to strategy, monitoring, and resource provision have shown mixed results in the handful of studies conducted to-date. This points to the need to develop the nascent literature further and to consider issues that so far have received only scant attention. These include:

Uses and audiences. Data on characteristics feed into the governance ratings used by investors and therefore have uses by external audiences. Policy has encouraged disclosure of increasing amounts of such data, not just about evaluation itself, but also data on director knowledge and skills, and proxies for effort norms (e.g. attendance at board and committee meetings) that contribute to board effectiveness. Yet we do not know how well such data indicate effectiveness without understanding how the evaluation of individual characteristics and behavior affect board decision processes. As the authors have argued elsewhere, ${ }^{51}$ when evaluation is intended as a tool for internal improvement, rather than for public consumption, it is important to consider the individual's strengths, the collective abilities of the board, and how board processes and input contribute to the outcomes (see Figure 1).

Process questions. Discussion in the literature about the timing and frequency of evaluations has been led by the policy direction: annual evaluations, less frequent but regular external facilitation. Less discussed are the circumstances under which evaluation might yield the greatest insights. For example, Stybel and Peabody worry about the possibility that a scheduled board evaluation might coincide with a major event (e.g. an initial public offering) and distract directors with questionnaires to complete. ${ }^{52}$ Yet that might be precisely the time to ask an external evaluator to observe board practice to assess interpersonal relations. Qualitative, ethnographic and case study research could help us determine what types of evaluations are beneficial in what types of circumstances. 


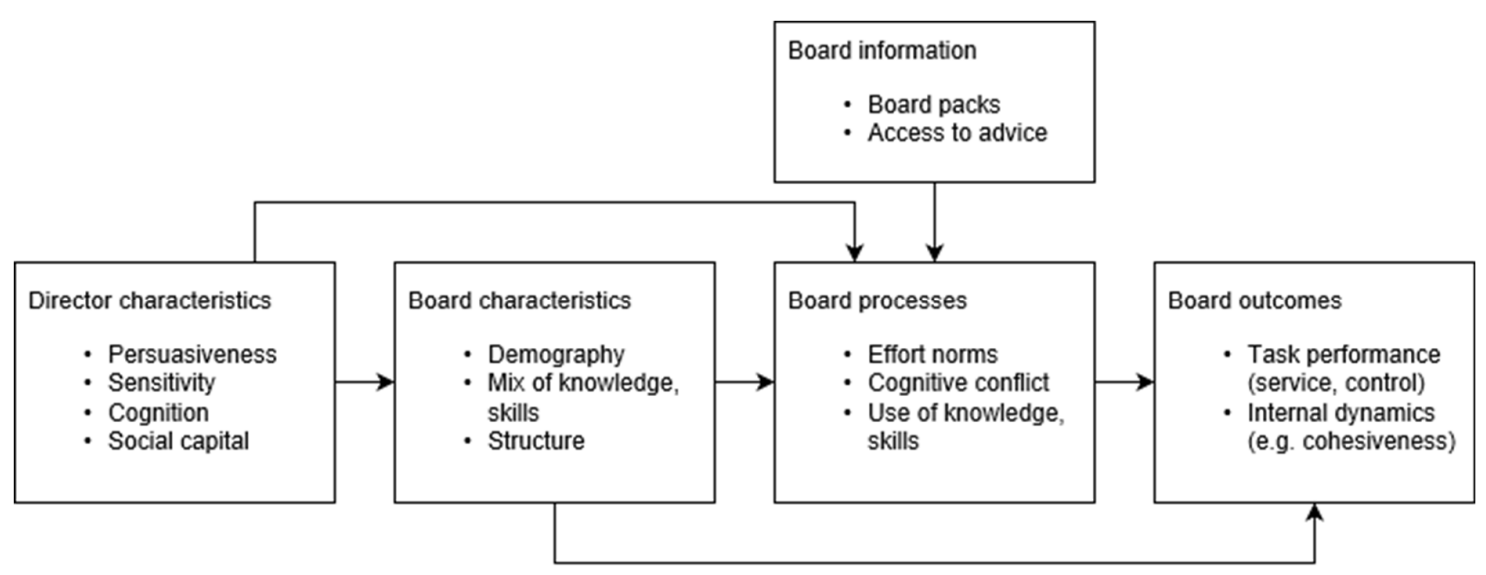

Figure 1 - Board evaluation process map (C Nordberg and Booth)

\section{Implications for practice and policy}

In a strongly policy-led field, there is a danger that practice may ignore the evidence. These multiple dimensions point toward complex approaches to board evaluation, which can be assembled in ways that deal with the peculiar circumstances of a board, at a particular time, in setting its objectives for internal development and the interpersonal accountability between directors. Demands of outside parties for vertical accountability may be satisfied by more systematic collection of data and publication of subsets of it that show the rigor. Equally, external audiences may draw sufficient comfort from the use of respected, professionally accredited facilitators. The discussion above leads us to wonder whether any one formula can satisfy the demands for board development and external accountability, that is, whether institutionalizing the process in detail is likely to lead to unintended consequences, and whether if recognized these can be outweighed by the importance of the process to safe-guard the company against those directing it.

\section{Conclusions}

Almost 70 years ago, in the pages of Harvard Business Review, Blair posed the puzzle of board appraisal, but asked corporations to take it seriously nonetheless. In the intervening decades, corporate governance has emerged as a major theme of corporate and public policy, exposing board processes to scrutiny, not least to identify ways like frequent evaluation for boards and directors to become more effective in keeping imperious CEOs and wayward management in check.

Writing much more recently in Harvard Business Review, Sonnenfeld et al. turned the spotlight in the opposite direction, asking CEOs to evaluate their boards. Their anecdotal accounts show CEOs concerned about the timidity of outside directors, their statusconsciousness, and their reluctance to stand down. They see these traits as impediments to corporate purpose, for example, preventing them from agreeing to accept a takeover bid that would benefit shareholders. ${ }^{53}$ 
These differing views point to the tensions concerning the nature of corporate governance, the forms of accountability, and the purposes and processes of board evaluation. This report suggests that board evaluation is a multidimensional practice that involves the complex interaction of concepts the consequences of which is just starting to be understood. If we regard the practice as a series of natural experiments, then policy might then be adjusted, in small steps. It might be taken as an opportunity to gather evidence, in ways that preserve the spirit of experimentation, thus avoiding premature institutionalization and providing a more solid base for a future policy regime. For boards, this report identifies many paths of experimentation, across multiple dimensions. Greater experience, across a broader range of cases, will help board identify what works, when, and for whom.

Table 1 - Advantages, drawbacks of board evaluation

\begin{tabular}{|c|c|c|c|c|}
\hline & Element & Benefits & $\begin{array}{l}\text { Drawbacks, sources of } \\
\text { potential manipulation }\end{array}$ & Comment \\
\hline \multirow[t]{2}{*}{ 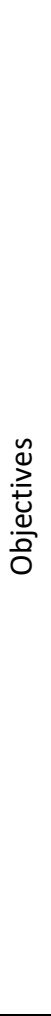 } & $\begin{array}{l}\text { Board } \\
\text { development }\end{array}$ & $\begin{array}{l}\text { Formal CEO evaluation } \\
\text { benefits director resource } \\
\text { provision; board } \\
\text { evaluation benefits } \\
\text { strategy work; in small } \\
\text { firms monitoring as well; } \\
\text { "exemplar" evaluations } \\
\text { show benefit in profits } \\
\text { Addresses "elephant in the } \\
\text { room"; assesses } \\
\text { knowledge, skills of } \\
\text { directors; performance; } \\
\text { understanding individuals, } \\
\text { group; opens dialogue on } \\
\text { strategy; board evaluation } \\
\text { as mechanism to examine } \\
\text { "constructive" conflict, } \\
\text { "interpersonal cohesion"; } \\
\text { benefits for board } \\
\text { effectiveness }\end{array}$ & $\begin{array}{l}\text { Formal CEO evaluation } \\
\text { process not significant } \\
\text { for director monitoring } \\
\text { Board evaluation may } \\
\text { be used to mechanism } \\
\text { to squeeze out directors }\end{array}$ & \multirow[t]{2}{*}{$\begin{array}{l}\text { Value pivots on intent: e.g. } \\
\text { orchestrating departures } \\
\text { can be beneficial to firm or } \\
\text { become mechanism for } \\
\text { concentrating power. } \\
\text { Focus on legitimacy at } \\
\text { expense of board } \\
\text { development can lead to } \\
\text { symbolic management }\end{array}$} \\
\hline & Legitimacy & $\begin{array}{l}\text { Signals commitment to } \\
\text { shareholder value; } \\
\text { conformance; benefits for } \\
\text { external perceptions of } \\
\text { board favorable D\&O } \\
\text { insurance }\end{array}$ & $\begin{array}{l}\text { Risk of creating paper } \\
\text { trail of deficiencies; } \\
\text { disclosures vague }\end{array}$ & \\
\hline 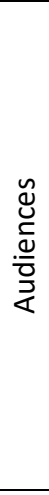 & Internal & $\begin{array}{l}\text { Trustees (of non-profits) } \\
\text { view benefits as board- } \\
\text { internal, see little benefit } \\
\text { for outsiders; evaluation } \\
\text { viewed as having intrinsic } \\
\text { value to directors, rather } \\
\text { than value creation for } \\
\text { firm } \\
\text { In family firms, formal } \\
\text { board evaluation } \\
\text { overcomes "fault-lines" } \\
\text { becoming crises }\end{array}$ & & $\begin{array}{l}\text { Value of evaluation may } \\
\text { come from less obvious } \\
\text { sources; evaluation can } \\
\text { help set aside internal board } \\
\text { hierarchies, re-establishing } \\
\text { directors as equals; } \\
\text { presence of evaluation } \\
\text { influences perceptions } \\
\text { concerning control } \\
\text { processes also as } \\
\text { contributing to value } \\
\text { creation, not just value } \\
\text { preservation }\end{array}$ \\
\hline
\end{tabular}




\begin{tabular}{|c|c|c|c|c|}
\hline & External & $\begin{array}{l}\text { Consider non-traditional } \\
\text { stakeholders, i.e., D\&O } \\
\text { insurers; also potential } \\
\text { acquirers; think of } \\
\text { regulators as audience }\end{array}$ & & \\
\hline \multirow{2}{*}{ 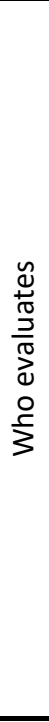 } & Board internal & $\begin{array}{l}\text { Self-assessment brings } \\
\text { benefits to board strategy } \\
\text { work } \\
\text { Chair-led evaluations } \\
\text { commonplace; need for, } \\
\text { issues in evaluation of } \\
\text { chair; by lead non- } \\
\text { executive director }\end{array}$ & $\begin{array}{l}\text { Self-assessments } \\
\text { sometimes involve } \\
\text { outsiders, blurring } \\
\text { distinctions between } \\
\text { the two forms; internal } \\
\text { assessment never } \\
\text { sufficient }\end{array}$ & \multirow{2}{*}{$\begin{array}{l}\text { Points to relevance of } \\
\text { viewing issue as a } \\
\text { continuum } \\
\text { Questions raised: } \\
\text { External verification of } \\
\text { factual content of self- } \\
\text { assessments? } \\
\text { Need to professionalize } \\
\text { board evaluators; verify } \\
\text { evaluation reports? }\end{array}$} \\
\hline & $\begin{array}{l}\text { External } \\
\text { facilitator }\end{array}$ & $\begin{array}{l}\text { Creates objectivity, open } \\
\text { avenue to discuss } \\
\text { interpersonal issues }\end{array}$ & $\begin{array}{l}\text { Resistance to outsiders } \\
\text { in boardroom; } \\
\text { objectivity requires } \\
\text { professionalism of } \\
\text { evaluators } \\
\text { Growing scope of } \\
\text { board evaluation raises } \\
\text { issue of capacity, } \\
\text { evaluator skills }\end{array}$ & \\
\hline \multirow[t]{2}{*}{ 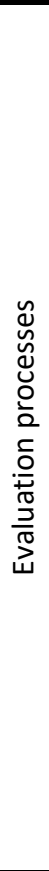 } & Systematic & $\begin{array}{l}\text { Formal tools ensure rigor, } \\
\text { enhance accountability; } \\
\text { questionnaires can capture } \\
\text { good view of inputs to } \\
\text { board processes; } \\
\text { contingencies can be } \\
\text { addressed through } \\
\text { examination of business } \\
\text { environment }\end{array}$ & $\begin{array}{l}\text { Director concern over } \\
\text { "mindless checklists", } \\
\text { "over-engineering" of } \\
\text { process; concern over } \\
\text { political aspects in } \\
\text { "horizontal" (peer) } \\
\text { evaluation as opposed } \\
\text { to "vertical" appraisal } \\
\text { of employees } \\
\text { US-style rules-based } \\
\text { approach perfunctory; } \\
\text { paralysis by analysis; } \\
\text { form over substance; } \\
\text { risks unhelpful } \\
\text { categorization of } \\
\text { directors }\end{array}$ & \multirow[t]{2}{*}{$\begin{array}{l}\text { Formality can impede } \\
\text { ability to see, } \\
\text { understanding board } \\
\text { dynamics, interpersonal } \\
\text { relations, contingencies of } \\
\text { business; risk of } \\
\text { increasingly detailed } \\
\text { assessment through } \\
\text { sedimentation of additional } \\
\text { requirements }\end{array}$} \\
\hline & Contingent & $\begin{array}{l}\text { Structure, content of } \\
\text { evaluation can be sensitive } \\
\text { to contingencies in board } \\
\text { structure, firm lifecycle, } \\
\text { culture; directors value } \\
\text { flexibility }\end{array}$ & & \\
\hline \multirow[t]{2}{*}{ 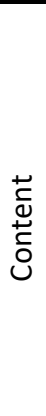 } & $\begin{array}{l}\text { Board } \\
\text { processes }\end{array}$ & $\begin{array}{l}\text { Focus of evaluation on } \\
\text { activities and resources of } \\
\text { the board, emphasizing } \\
\text { strategic role; inputs, } \\
\text { including information; } \\
\text { processes, including } \\
\text { information management }\end{array}$ & & \multirow{2}{*}{$\begin{array}{l}\text { Content-oriented analyses } \\
\text { look mainly at inputs } \\
\text { (knowledge, skills, } \\
\text { information), structures } \\
\text { (board design, committees), } \\
\text { and activities (meeting } \\
\text { schedules, agendas, } \\
\text { attendance); this focus may } \\
\text { overlook relational issues }\end{array}$} \\
\hline & Interpersonal & $\begin{array}{l}\text { Interpersonal development } \\
\text { viewed as prime benefit of } \\
\text { evaluation process }\end{array}$ & & \\
\hline
\end{tabular}




\begin{tabular}{|c|c|c|c|c|}
\hline & Comprehensive & $\begin{array}{l}\text { Evaluation can get to three } \\
\text { levels: board, committees, } \\
\text { directors }\end{array}$ & $\begin{array}{l}\text { Lack of engagement } \\
\text { threatens success of } \\
\text { evaluation }\end{array}$ & \\
\hline 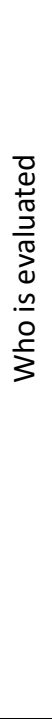 & Selective & $\begin{array}{l}\text { CEO evaluation different: } \\
\text { consider 360-degree } \\
\text { including external } \\
\text { stakeholders } \\
\text { Audit committee } \\
\text { evaluation results reveals } \\
\text { lack of attention to skills } \\
\text { development } \\
\text { Decision whether to } \\
\text { evaluate CEO contingent } \\
\text { on organization } \\
\text { circumstances } \\
\text { Evaluation of chairs } \\
\text { important, as leadership is } \\
\text { crucial to board } \\
\text { effectiveness }\end{array}$ & $\begin{array}{l}\text { Resistance to } \\
\text { evaluation of individual } \\
\text { directors }\end{array}$ & $\begin{array}{l}\text { Structure of evaluation } \\
\text { process, not just the } \\
\text { evaluation itself, can be a } \\
\text { political decision, with } \\
\text { beneficial and manipulative } \\
\text { outcomes, provoking } \\
\text { resistance to process, loss } \\
\text { of candor }\end{array}$ \\
\hline
\end{tabular}

\footnotetext{
${ }^{1}$ Taylor Griffin et al., "Board Evaluations and Boardroom Dynamics," Stanford University Graduate School of Business, https://ssrn.com/abstract=2927273. Alessandro Minichilli, Jonas Gabrielsson, and Morten Huse, "Board Evaluations: Making a Fit between the Purpose and the System," Corporate Governance: An international review 15, no. 4 (2007).

${ }^{2}$ Eugene F. Fama and Michael C. Jensen, "Separation of Ownership and Control," Journal of Law and Economics 23, no. 2 (1983).

${ }^{3}$ Donald Nordberg and Terry McNulty, "Creating Better Boards through Codification: Possibilities and Limitations in Uk Corporate Governance, 1992-2010," Business History 55, no. 3 (2013).

${ }^{4}$ David Archer and Alex Cameron, "Board Evaluations," Governance Newsletter, no. 275 (2017); Bob Garratt, "Developing Effective Directors and Building Dynamic Boards," Long Range Planning 32, no. 1 (1999); Richard Leblanc, "Assessing Board Performance: 10 Key Factors," Corporate Board 23, no. 132 (2002); McKinsey \& Co., "Governance since the Economic Crisis: Mckinsey Global Survey Results," https://www.mckinseyquarterly.com/PDFDownload.aspx?ar=2814\&srid=17.

${ }^{5}$ Spencer Stuart, "Boards around the World: Board Assessment," https://www.spencerstuart.com/research-andinsight/boards-around-the-world.

${ }^{6}$ Wilbur T. Blair, "Appraising the Board of Directors," Harvard Business Review 28, no. 1 (1950).

${ }^{7}$ Thomas P. Holland, "Self-Assessment by Nonprofit Boards," Nonprofit Management and Leadership 2, no. 1 (1991). Holland's critique took issue, among others, with John Carver, Boards That Make a Difference: A New Design for Leadership in Nonprofit and Public Organizations (San Francisco: Jossey-Bass, 1990).

${ }^{8}$ Adrian Cadbury, "What Are the Trends in Corporate Governance? How Will They Affect Your Company?," Long Range Planning 32, no. 1 (1999). John Kazanjian, "Assessing Boards and Individual Directors," Ivey Business Journal 64, no. 5 (2000).

${ }^{9}$ A European Green Paper on corporate governance gave similar advice to the 2010 UK code; see European Commission, "Green Paper: The Eu Corporate Governance Framework,"

http://ec.europa.eu/internal_market/company/docs/modern/com2011-164_en.pdf. This language did not appear, however, in the subsequent action plan; see "Action Plan: European Company Law and Corporate Governance - a Modern Legal Framework for More Engaged Shareholders and Sustainable Companies " http://eurlex.europa.eu/legal-content/EN/TXT/PDF/?uri=CELEX:52012DC0740\&from=EN.

${ }^{10}$ Garratt, "Developing Effective Directors and Building Dynamic Boards."
} 
11 Jay A. Conger, David Finegold, and Edward E. Lawler, III, "Appraising Boardroom Performance," Harvard Business Review 76, no. 1 (1998); Jeffrey A. Sonnenfeld, "What Makes Great Boards Great," ibid.80, no. 9 (2002).

12 Tracy Long, "This Year's Model: Influences on Board and Director Evaluation," Corporate Governance: An international review 14, no. 6 (2006).

${ }^{13}$ McKinsey \& Co., "Governance since the Economic Crisis: Mckinsey Global Survey Results".

${ }^{14}$ PwC, "Trends Shaping Governance and the Board of the Future," PricewaterhouseCoopers, https://www.pwc.com/us/en/corporate-governance/annual-corporate-directors-survey/assets/annual-corporatedirectors-survey-full-report-pwc.pdf.

${ }^{15}$ Spencer Stuart, "Boards around the World: Board Assessment".

${ }^{16}$ Conger, Finegold, and Lawler, "Appraising Boardroom Performance."

${ }^{17}$ Geoffrey C. Kiel, Gavin J. Nicholson, and Mary Ann Barclay, Board, Director and Ceo Evaluation, Australia Business Profession Reference (Sydney: McGraw-Hill, 2005).

${ }^{18}$ Minichilli, Gabrielsson, and Huse, "Board Evaluations: Making a Fit between the Purpose and the System."

${ }^{19}$ Catherine M. Daily and Dan R. Dalton, "Looking in the Mirror: Board Evaluation," Journal of Business Strategy 24, no. 6 (2003).

${ }^{20}$ Marc J. Epstein and Marie-Josée Roy, "Improving the Performance of Corporate Boards: Identifying and Measuring the Key Drivers of Success," Journal of General Management 29, no. 3 (2004); Sascha L. Schmidt and Matthias Brauer, "Strategic Governance: How to Assess Board Effectiveness in Guiding Strategy Execution," Corporate Governance: An International Review 14, no. 1 (2006).

${ }^{21}$ Ahmed Hussein Aly and Mohamed Elsayed Mansour, "Evaluating the Sustainable Performance of Corporate Boards: The Balanced Scorecard Approach," Managerial Auditing Journal 32, no. 2 (2017); Loizos Heracleous and Luh Luh Lan, "Who Wants to Be a Competent Director?: An Evaluation Tool of Directors' Knowledge of Governance Principles and Legal Duties," Corporate Governance: The international journal of business in society 2, no. 4 (2002).

${ }^{22}$ Lutgart A.A. Van den Berghe and Abigail Levrau, "Evaluating Boards of Directors: What Constitutes a Good Corporate Board?," Corporate Governance: An International Review 12, no. 4 (2004).

${ }^{23}$ Andrew Likierman, "Measuring the Success of the Board," http://www.ifac.org/system/files/publications/files/measuring-the-success-of-the-board.pdf.

${ }^{24}$ IoD, "The 2017 Good Governance Report," Institute of Directors, https://www.iod.com/Portals/0/PDFs/Campaigns\%20and\%20Reports/Corporate\%20Governance/GGI-report2017-IoD.pdf.

${ }^{25}$ Coral B. Ingley and Nicholas T. Van der Walt, "The Strategic Board: The Changing Role of Directors in Developing and Maintaining Corporate Capability," Corporate Governance: An International Review 9, no. 3 (2001).

${ }^{26}$ Geoffrey C. Kiel and Gavin J. Nicholson, "Evaluating Boards and Directors," ibid.13, no. 5 (2005); Kiel, Nicholson, and Barclay, Board, Director and Ceo Evaluation; Gavin J. Nicholson and Geoffrey C. Kiel, "A Framework for Diagnosing Board Effectiveness," Corporate Governance: An International Review 12, no. 4 (2004).

${ }^{27}$ Minichilli, Gabrielsson, and Huse, "Board Evaluations: Making a Fit between the Purpose and the System."

${ }^{28}$ Laurence J. Stybel and Maryanne Peabody, "How Should Board Directors Evaluate Themselves?,"

http://sloanreview.mit.edu/article/how-should-board-directors-evaluate-themselves/?article=how-should-boarddirectors-evaluate-themselves.

${ }^{29}$ Susan P. Jauncey and David N. Moseley-Greatwich, "The Validity of Measuring Director and Board Performance: Continuum or Categorisation?," International Journal of Business Governance and Ethics 3, no. 3 (2007); Long, "This Year's Model: Influences on Board and Director Evaluation."

${ }^{30}$ Margriet Groothuis, "Board Evaluations in Practice: A Practical Take-out for De Nederlandsche Bank," http://arno.uva.nl/document/351646.

${ }^{31}$ Griffin et al., "Board Evaluations and Boardroom Dynamics".

${ }^{32}$ Gavin J. Nicholson, Geoffrey C. Kiel, and Jennifer Ann Tunny, "Board Evaluations: Contemporary Thinking and Practice," in The Sage Handbook of Corporate Governance, ed. Thomas Clarke and Douglas Branson (London: Sage, 2012).

${ }^{33}$ Sylvie Berthelot, Jackie Di Vito, and Vincent Gagné, "Evaluating the Performance of Board Members: A Portrait of Canadian Firms," Corporate Ownership and Control 8, no. 3 (2011); Rebecca Booth and Donald Nordberg, "Self or Other: Directors' Attitudes Towards Policy Initiatives for External Board Evaluation," in International Corporate Governance Society (Rome2017); Tor Brunzell and Sten Söderman, "Board Evaluation in the Top Nordic Football Clubs," Sport, Business and Management: An International Journal 2 , no. 3 (2012); Peter Sponbergs, "Evaluation of Board Work in Fifteen Companies Belonging to the City of Stockholm," Corporate Governance: An International Review 15, no. 2 (2007). 
${ }^{34}$ Coral B. Ingley and Nicholas T. Van der Walt, "Board Dynamics and the Politics of Appraisal," ibid.10, no. 3 (2002).

35 Victor Dulewicz and Peter Herbert, "Current Practice of Ftse 350 Boards Concerning the Appointment, Evaluation and Development of Directors, Boards and Committees Post the Combined Code," International Journal of Business Governance and Ethics 4, no. 1 (2008). See also Nicholson, Kiel, and Tunny, "Board Evaluations: Contemporary Thinking and Practice."

36 Thomas Clarke and Alice Klettner, "Board Effectiveness \& Performance: The State of Play on Board Evaluation in Corporate Australia and Abroad," https://www.acsi.org.au/images/stories/ACSIDocuments/generalresearchpublic/10\%20Board\%20Effectiveness $\% 20 \% 20$ Performance\%20Research\%20Paper.pdf.

${ }^{37}$ Mattias Nordqvist and Alessandro Minichilli, "What Makes Boards in Small Firms Active?," in The Value Creating Board: Corporate Governance and Organizational Behaviour, ed. Morten Huse (Abingdon: Routledge, 2009).

${ }^{38}$ Silke Machold et al., "Board Leadership and Strategy Involvement in Small Firms: A Team Production Approach," Corporate Governance: An International Review 19, no. 4 (2011).

${ }^{39}$ Marie-Josée Roy, "Characterizing Performance Evaluation Systems for Corporate Directors," Proceedings of the European Conference on Management, Leadership \& Governance (2015).

${ }^{40}$ Esther B. Del Brio et al., "The Effects of Ceo Trustworthiness on Directors' Monitoring and Resource Provision," Journal of Business Ethics 118, no. 1 (2013).

${ }^{41}$ Booth and Nordberg, "Self or Other: Directors' Attitudes Towards Policy Initiatives for External Board Evaluation."

${ }^{42}$ Kiel and Nicholson, "Evaluating Boards and Directors."

${ }^{43}$ Minichilli, Gabrielsson, and Huse, "Board Evaluations: Making a Fit between the Purpose and the System."

${ }^{44}$ Gary J. Cundill, Palie Smart, and Hugh N. Wilson, "Non-Financial Shareholder Activism: A Process Model for Influencing Corporate Environmental and Social Performance," International Journal of Management Reviews 20, no. 2 (2017); Peer C. Fiss and Edward J. Zajac, "The Symbolic Management of Strategic Change: Sensegiving Via Framing and Decoupling," Academy of Management Journal 49, no. 6 (2006).

${ }^{45}$ Michael L. McIntyre and Steven A. Murphy, "Board of Director Performance Reporting," Corporate Governance: The international journal of business in society 8, no. 2 (2008).

${ }^{46}$ Kiel and Nicholson, "Evaluating Boards and Directors." Minichilli, Gabrielsson, and Huse, "Board Evaluations: Making a Fit between the Purpose and the System; Stybel and Peabody, "How Should Board Directors Evaluate Themselves?".

${ }^{47}$ John Roberts, "Trust and Control in Anglo-American Systems of Corporate Governance: The Individualizing and Socializing Effects of Processes of Accountability," Human Relations 54, no. 12 (2001).

${ }^{48}$ Long, "This Year's Model: Influences on Board and Director Evaluation; Spencer Stuart, "Boards around the World: Board Assessment".

${ }^{49}$ Roger Kenny, "Lessons Learned in Board Assessment," Corporate Board 37, no. 220 (2016).

${ }^{50}$ ABExcellence, "Board Review Code of Practice," Advanced Boardroom Excellence, http://www.abexcellence.com/board-review-code-of-practice; Booth and Nordberg, "Self or Other: Directors' Attitudes Towards Policy Initiatives for External Board Evaluation."

${ }^{51}$ Donald Nordberg and Rebecca Booth, "Evaluating the Effectiveness of Corporate Boards," Corporate Governance: The International Journal of Business in Society 19, no. 2 (2019).

52 Stybel and Peabody, "How Should Board Directors Evaluate Themselves?".

${ }^{53}$ Jeffrey Sonnenfeld, Melanie Kusin, and Elise Waltonz, "What Ceos Really Think of Their Boards," Harvard Business Review 91, no. 4 (2013). 